\title{
Fertilizer Recommendations based on Targeted Yield Concept Involving INM for Potato (Solenum Tuberosum L) in Inceptisols of Rainfed Midlands of Bastar Plateau
}

\author{
R. Mandal and G.K. Sharma* \\ Saheed Gundadhoor College of Agriculture and Research Station, Jagdalpur-494 005 \\ (Bastar), Chhattisgarh, India \\ *Corresponding author
}

\section{A B S T R A C T}

\section{Keywords}

Fertilizer

recommendation,

Potato (Solenum

tuberosum L),

Midland inceptisols,

Targeted yield

approach, INM for

potato

Article Info

Accepted:

12 June 2019

Available Online:

10 July 2019

\begin{abstract}
Soil test crop response correlation study was carried out in midland inceptisols of Bastar plateau zone of Chhattisgarh (India) during 2012-13 taking potato (kufri pukhraj) as test crop to quantify production in the context of the variability of soil properties and recommendation of balanced fertilizers with organic manure based on targeted yield concept. The basic data required for formulation of fertilizer recommendation is derived from this experiment. Nutrient required to produce one quintal of potato tuber was found to be $0.48 \mathrm{~kg} \mathrm{~N}, 0.11 \mathrm{~kg} \mathrm{P}$ and $0.52 \mathrm{~kg} \mathrm{~K}$, respectively. The fertilizer efficiencies of $\mathrm{N}, \mathrm{P}$ and $\mathrm{K}$ for potato crop were estimated as 32.94, 28.30 and 97.40 per cent, respectively. The efficiencies of soil test values were 16.42, 64.47 and 18.33 per cent for $\mathrm{N}, \mathrm{P}$ and $\mathrm{K}$, respectively. The efficiencies of organic source (FYM) were observed as 11.09, 5.88, 5.55 per cent for N, P and K, respectively. With the help of above basic data base, the fertilizer recommendation equations and the ready reckoner was developed which will be useful for soil test based balanced and integrated nutrient management in potato crop under midlands and other similar soil and agro-climatic conditions.
\end{abstract}

\section{Introduction}

India is the third largest producer of potato (Solanum tuberosum L.) in the world after China and Russia. The average productivity of potato in India and Chhattisgarh state is 22.70 and $16.8 \mathrm{t} \mathrm{ha}^{-1}$ respectively (Anonymous, 2011). In Bastar region, with limited irrigation facility, potato is gaining popularity due to favourable climate (Sharma and Chaudhary, 2014). It is a heavy feeder of plant nutrients having high requirement of nitrogen, phosphorus, potassium and other nutrients. To increase the crop productivity, use of high-yielding varieties with optimum levels of inputs is very much needed, but the decision on fertilizer use would require an indepth knowledge of the expected crop yield response to nutrient application, which is a function of crop nutrient needs, supply of nutrients from indigenous sources, and the short and long-term fate of the fertilizer doses applied to a soil (Doberman et al., 2003). In the light of ever-increasing prices coupled with increasing demand of chemical fertilizers and depleting soil fertility with respect to 
availability of different nutrients, there is an urgent need to shift to integrated organic and inorganic sources of nutrients for sustainable crop production and soil health (Singh et al., 2014 and Kumar et al., 2014).

Several approaches have been used for fertilizer recommendation based on chemical soil test so as to attain maximum yield per unit of fertilizer use. Among the various approaches, the target yield approach given by Troug (1960), which was further modified by Ramamoorthy et al., (1967) has found popularity in India (Subba Rao and Srivastava, 2000). The data obtained from the targeted yield experiment provides a range in soil test values, nutrient uptake and yield levels which enable in calculating the 4 basic parameters as nutrient requirement, per cent contribution of available nutrient from soils (CS), the per cent contribution from the applied fertilizer (CF) and the per cent contribution from organic manures (CFYM).

Quantitative fertilizer requirements based on this approach have been estimated for specific yield target of crops like maize, rice and chickpea (Mandal et al., 2016; Sharma et al., 2015; Mishra et al., 2015; Regar and Singh, 2014). Recommendations based on Soil Test Crop Response Correlation concept are more quantitative, precise and meaningful because combined use of soil and plant analysis is involved in it. It gives a real balance between applied nutrients and the available nutrients already present in the soil. Keeping above factors in view and lack of quantitative information on fertilizer doses with organic manures based on target yield for 'Kufri pukhraj' potato in Bastar plateau of Chhattisgarh, this study was conducted.

\section{Materials and Methods}

A field experiment was conducted based on STCR methodology on potato with the variety 'kufri pukhraj' at Shaheed Gundadhoor College of Agriculture and Research Station, Kumharawand, Jagdalpur, Bastar district of Chhattisgarh (India) during Rabi season, 2013-14 after harvest of maize experiment during kharif season, 2013. The field was prepared without any disturbance to the already created three fertility gradient strips $\left(\mathrm{L}_{0}, \mathrm{~L}_{1}\right.$, and $\left.\mathrm{L}_{2}\right)$. Then each strip was sub divided into 24 plots of equal size. A set of 24 treatments out of which 21 treatments in combination with four levels of nitrogen $(0$, 60, 120 and $180 \mathrm{~kg} \mathrm{ha}^{-1}$ ), four levels of phosphorus $\left(0,30,60\right.$ and $\left.90 \mathrm{~kg} \mathrm{ha}^{-1}\right)$ four levels of potassium $\left(0,30,60\right.$ and $\left.90 \mathrm{~kg} \mathrm{ha}^{-1}\right)$ and three levels of FYM $\left(0,5,10 \mathrm{t} \mathrm{ha}^{-1}\right)$ and three controls were superimposed to different plots in each strip and the experiment was conducted in a randomized block design (RBD). Initial soil samples were collected from each sub-plot $(0-15 \mathrm{~cm})$ before superimposition of 21 fertilizer treatments and three controls were analyzed for available nitrogen by alkaline potassium permanganate method as proposed by Subbiah and Asija (1956), available phosphorus by Bray's method (Bray, 1948) and available potassium by ammonium acetate method (Hanway and Heidal, 1952) as described by Jackson (1973). The plant samples tuber as well as straw collected at harvesting stage has been analyzed for $\mathrm{N}, \mathrm{P}$ and $\mathrm{K}$ and the plant uptake of nutrients was calibrated by using tuber and straw yield data. Nitrogen content of plant samples was determined using method as described by Chapman and Pratt (1961), Phosphorus content was determined by vanadomolybdo-phosphoric acid yellow color complex method as described by Jackson (1973) and Potassium content was determined by flame photometer as described by Chapman and Pratt (1961).

Using the tuber yield and nutrient uptake data, soil test values and applied fertilizer does of treated and control plots, the basic data viz. 
nutrient requirement (NR) $\left(\mathrm{kg} \mathrm{q}^{-1}\right)$, percent contribution from the soil available nutrients [CS, \%] and the percent contribution from the applied fertilizer nutrients [CF, \%] were derived and used to calibrate the fertilizer adjustment equations (Velayutham et al., 1985a; Rao and Srivastava, 2000).

$F=\frac{\text { NR }}{\text { Cf }} Y-\frac{\text { Cs }}{\text { Cf }} S-\frac{\text { CFYM }}{\text { Cf }} F Y M$

Where,

$\mathrm{F}=$ Fertilizer $\left(\mathrm{kg} \quad \mathrm{ha}^{-1}\right), \quad \mathrm{NR}=$ Nutrient requirement of $\mathrm{N}$ or $\mathrm{P}_{2} \mathrm{O}_{5}$ or $\mathrm{K}_{2} \mathrm{O} \mathrm{kg} \mathrm{q}$ produce, $\mathrm{Cs}=$ Per cent contribution from soil, $\mathrm{Cf}=$ Per cent contribution from fertilizer, CFYM =Per cent contribution from FYM, $\mathrm{S}=$ Soil test value for available $\mathrm{N}, \mathrm{P}$ or $\mathrm{K}(\mathrm{kg}$ $\left.\mathrm{ha}^{-1}\right), \quad \mathrm{Y}=$ Yield target $\left(\mathrm{q} \quad \mathrm{ha}^{-1}\right)$ and FYM=Farmyard manure $\left(\mathrm{t} \mathrm{ha}^{-1}\right)$

Standard regression procedure was used to relate the soil test and fertilizer with crop yield response (Draper and Smith, 1998). The nutrient requirement, soil, fertilizer and farm yard manure efficiencies were derived as discussed by Velayutham et al., (1985b) and Maruthi Sankar (1986). The experiment was conducted on the basis of whole field method in which the data of all plots were used in deriving the estimates. The soil efficiency was estimated from only unfertilized plots, while the fertilizer and organic manure efficiency was estimated from fertilized plots.

The nutrient requirement was estimated from both the fertilized and unfertilized plots. The computational procedure of basic data is well discussed in Ramamoorthy et al., (1967). The estimates of basic data were used for developing fertilizer adjustment equations for deriving optimum fertilizer doses for achieving different yield targets. The soil test based fertilizer recommendations can be prescribed in the form of a ready reckoner for different yield targets.

\section{Results and Discussion}

\section{Soil available nutrients}

Soil samples from each plot were taken before conducting the main experiments and analyzed for available $\mathrm{N}, \mathrm{P}$ and $\mathrm{K}$. The range and mean soil test values of available $\mathrm{N}, \mathrm{P}$ and $\mathrm{K}$ nutrients before sowing of experiment during rabi season 2013-14 are given in Table 1. The results showed that the available nitrogen ranged between 192 and 250 with a mean of $218 \mathrm{~kg} \mathrm{ha}^{-1}$, available phosphorus from 6.20 to 40.50 with a mean of $21.7 \mathrm{~kg} \mathrm{ha}^{-}$ ${ }^{1}$, and available potassium between 169 and 320 with a mean of $246 \mathrm{~kg} \mathrm{ha}^{-1}$.

It is evident from the above data that wide variability has existed in the soil test values among fertility strips which is essential for developing a multiple regression model, basic data and targeted yield equations for calibrating the optimum fertilizer dose. The soil test data indicate that available $\mathrm{N}, \mathrm{P}$ and $\mathrm{K}$ varied with different fertility strips although available $\mathrm{N}$ and $\mathrm{K}$ variations with respect to fertility strip were marginal however, available $\mathrm{P}$ variation in different strips were quite marked and it increased across the fertility strips.

Gradient with respect to available $\mathrm{P}$ was observed clearly due to immobile nature of $\mathrm{P}$ and fixed with soil constituents to form insoluble compounds depending on the nature of soil and thus remains in soil. However, there was no gradient created with respect to $\mathrm{N}$ and $\mathrm{K}$ as the nature of $\mathrm{N}$ in soil is very dynamic and its different forms are subjected to losses through leaching, volatilization and de-nitrification. Average $\mathrm{K}$ status of the experimental field soil was in medium level and maintenance of its dynamic equilibrium might be the possible reason for almost the same mean soil test $\mathrm{K}$ levels in all strips. 


\section{Tuber yield of potato}

The range and average values of potato yields in relation to three fertility strips during $r a b i$ seasons 2013-14 are given in Table 1. The over all potato yields were recorded in the range from 56.82-205.92 $\mathrm{q} \mathrm{ha}^{-1}$ with an average of $144.59 \mathrm{q} \mathrm{ha}^{-1}$. There was an increasing trend in the tuber yields from $\mathrm{L}_{0}$ to $\mathrm{L}_{2}$ strip. It was observed that standard deviation (SD) and coefficient of variation $(\mathrm{CV} \%)$ were higher in $\mathrm{L}_{0}$ strip and declined under $L_{1}$ and $L_{2}$ strip indicating thereby that yield variations were higher in $\mathrm{L}_{0}$ strip due to soil nutrients variation. The increase in potato tuber yields with respect to fertility strips may be due to fertility gradient in soil $\mathrm{P}$ status from $\mathrm{L}_{0}$ to $\mathrm{L}_{2}$.

\section{Crop response to added fertilizer doses and FYM}

The crop responses to fertilizer N, P, K and FYM have been depicted in Figures 1 to 4 which showed that good crop responses to the fertilizer $\mathrm{N}$ and $\mathrm{P}$ application were observed with potato whereas crop response to $\mathrm{K}$ application was less consistent. Crop response to FYM application was not quite marked as shown in Figure 4. The relation of potato yields with different plant nutrients as independent variables were derived by regression analysis to evaluate the yield variations due to various nutrients and presented in the Table 2. Results indicate that the larger proportion of variation in tuber yields of potato was accounted for by $\mathrm{N}$ alone. Higher crop responses were attributed to the high $\mathrm{N}$ requirement and being a mobile nature of this element, it is easily accessible to the plant in the root system sorption zone (Ramamoorthy et al., 1967). Fertilizer $\mathrm{P}_{2} \mathrm{O}_{5}$ and $\mathrm{K}_{2} \mathrm{O}$ were the next to explained the rest of variations. The $\mathrm{P}$ ions react very quickly with soil constituents to form insoluble compounds and are thus rendered immobile in the soil. Furthermore, the requirement of $\mathrm{P}$ nutrient in potato was lower than $\mathrm{N}$. The curvilinear nature of potato yield responses to $\mathrm{P}$ application also did not reflect on yield variation due to poor $\mathrm{R}^{2}$ value as compared to linear relationship. The yield variation due to FYM application was also accounted very poor correlation. However, $89.0 \%$ of the yield variations were estimated due to fertilizer $\mathrm{N}$ and $\mathrm{P}$ only as reflected in the equation. Curvilinear relation of fertilizer $\mathrm{N}$ and $\mathrm{P}$ did not reflect on yield variations.

\section{Relationship between yield and nutrient uptake and estimation of nutrient requirement $(\mathrm{NR})$}

The yield of potato crop showed the close association with total $\mathrm{N}, \mathrm{P}$ and $\mathrm{K}$ uptake (Table 3). This relation was used to estimate the nutrient requirement for potato (Table 3). The nutrient requirement is defined as the amount of nutrient required to produce per unit amount of yield. The nutrient requirement can be given by the regression coefficient $\left(\mathrm{b}_{1}\right)$ of yield $(\mathrm{Y})$ and total nutrient uptake (U).

\section{$Y=b_{1} U$ or $U=1 / b_{1} * Y$}

Where, $1 / b_{1}$ gives the NR.

The amount of nutrients absorbed by the crop decides a definite amount of biomass production. Nutrient requirements for potato crop has been estimated based on conventional and regression methods which are almost similar values and are shown in the Table 3 and depicted graphically in Figures 57 showing a close association between crop yields and nutrient uptake with almost a linear relationship. The amount of nutrient required to produce one quintal of potato tuber was found to be $0.48 \mathrm{~kg} \mathrm{~N}, 0.11 \mathrm{~kg} \mathrm{P}$ and $0.52 \mathrm{~kg}$ $\mathrm{K}$. The nutrient requirement is also estimated by the conventional method as given below:

NR $(\mathrm{kg} / \mathrm{q})=\frac{\text { Total Nutrient Uptake }(\mathrm{kg} / \mathrm{ha})}{\text { Grain Yield }(\mathrm{q} / \mathrm{ha})}$ 
Table.1 Range and mean values of initial soil available N, P and K and tuber yield of potato crop (variety- Kufri pukhraj)

\begin{tabular}{|c|c|c|c|c|c|}
\hline Fertility strips & Minimum & Maximum & Mean & SD & CV (\%) \\
\hline \multicolumn{6}{|c|}{ Alkaline $\mathrm{KMnO}_{4}-\mathrm{N}\left(\mathrm{kg} \mathrm{ha}^{-1}\right)$} \\
\hline $\mathbf{L}_{\mathbf{0}}$ & 192 & 243 & 214 & 13.11 & 6.13 \\
\hline $\mathbf{L}_{1}$ & 192 & 250 & 220 & 15.72 & 7.15 \\
\hline $\mathbf{L}_{2}$ & 194 & 238 & 221 & 12.53 & 5.67 \\
\hline All strips & 192 & 250 & 218 & 14.04 & 6.44 \\
\hline \multicolumn{6}{|c|}{ Bray's-P (kg ha' $\left.{ }^{-1}\right)$} \\
\hline $\mathbf{L}_{\mathbf{0}}$ & 6.2 & 29.4 & 15.8 & 6.30 & 39.87 \\
\hline $\mathbf{L}_{1}$ & 8.9 & 35.7 & 20.8 & 7.01 & 33.70 \\
\hline $\mathbf{L}_{2}$ & 15.2 & 40.5 & 28.5 & 6.82 & 23.93 \\
\hline All strips & 6.2 & 40.5 & 21.7 & 8.45 & 38.94 \\
\hline \multicolumn{6}{|c|}{$\mathrm{NH}_{4} \mathrm{OAc}-\mathrm{K}\left(\mathrm{kg} \mathrm{ha}^{-1}\right)$} \\
\hline $\mathbf{L}_{0}$ & 169 & 285 & 207 & 26.95 & 13.00 \\
\hline $\mathbf{L}_{1}$ & 201 & 315 & 256 & 40.56 & 15.84 \\
\hline $\mathbf{L}_{2}$ & 227 & 320 & 274 & 25.65 & 9.36 \\
\hline All strips & 169 & 320 & 246 & 42.20 & 17.15 \\
\hline \multicolumn{6}{|c|}{ Potato Tuber Yield (q ha ${ }^{-1}$ ) } \\
\hline $\mathbf{L}_{\mathbf{0}}$ & 56.82 & 205.92 & 134.18 & 44.33 & 33.04 \\
\hline $\mathbf{L}_{1}$ & 64.34 & 201.07 & 146.29 & 42.77 & 29.24 \\
\hline $\mathbf{L}_{2}$ & 68.38 & 204.82 & 153.31 & 44.38 & 28.95 \\
\hline All strips & 56.82 & 205.92 & 144.59 & 43.94 & 30.39 \\
\hline
\end{tabular}

Table.2 Selected regression model to account for yield variation of potato

\begin{tabular}{|c|l|c|}
\hline S. No. & \multicolumn{1}{|c|}{ General regression models } & $\mathbf{R}^{\mathbf{2}}$ \\
\hline $\mathbf{1}$ & $\mathrm{Y}=80.31+0.597 \mathrm{FN}$ & $\mathbf{0 . 7 3 1}$ \\
\hline $\mathbf{2}$ & $\mathrm{Y}=85.83+1.175 \mathrm{FP}$ & $\mathbf{0 . 6 3 4}$ \\
\hline $\mathbf{3}$ & $\mathrm{Y}=107.5+0.800 \mathrm{FK}$ & $\mathbf{0 . 2 7 7}$ \\
\hline $\mathbf{4}$ & $\mathrm{Y}=139.3+1.042 \mathrm{FYM}$ & $\mathbf{0 . 0 0 9}$ \\
\hline $\mathbf{5}$ & $\mathrm{Y}=79.03+0.650 \mathrm{FN}-0.000 \mathrm{FN}^{2}$ & $\mathbf{0 . 7 3 1}$ \\
\hline $\mathbf{6}$ & $\mathrm{Y}=78.43+1.766 \mathrm{FP}-0.006 \mathrm{FP}^{2}$ & $\mathbf{0 . 6 5 2}$ \\
\hline & \multicolumn{1}{|c}{ Nutrient substitution models } & \\
\hline $\mathbf{7}$ & $\mathrm{Y}=66.767+0.414 \mathrm{FN}+0.667 \mathrm{FP}$ & $\mathbf{0 . 8 6 6}$ \\
\hline $\mathbf{8}$ & $\mathrm{Y}=66.252+0.411 \mathrm{FN}+0.653 \mathrm{FP}+0.033 \mathrm{FK}$ & $\mathbf{0 . 8 6 7}$ \\
\hline $\mathbf{9}$ & $\mathrm{Y}=61.039+0.411 \mathrm{FN}+0.653 \mathrm{FP}+0.033 \mathrm{FK}+1.043 \mathrm{FYM}$ & $\mathbf{0 . 8 7 6}$ \\
\hline $\mathbf{1 0}$ & $\mathrm{Y}=75.10+0.59 \mathrm{FN}+1.04 \mathrm{FYM}$ & $\mathbf{0 . 7 4 0}$ \\
\hline $\mathbf{1 1}$ & $\mathrm{Y}=47.53+0.16 \mathrm{SN}+0.57 \mathrm{FN}$ & $\mathbf{0 . 7 3 0}$ \\
\hline $\mathbf{1 2}$ & $\mathrm{Y}=\mathbf{8 4 . 5 2 + \mathbf { 0 . 1 0 S P } + \mathbf { 1 . 1 5 F P }}$ & $\mathbf{0 . 6 3 0}$ \\
\hline
\end{tabular}

Where, FN, FP and FK are fertilizer $\mathrm{N}, \mathrm{P}_{2} \mathrm{O}_{5}$, and $\mathrm{K}_{2} \mathrm{O}\left(\mathrm{Kg} \mathrm{ha}^{-1}\right)$ respectively. FYM is Farm Yard Manure (t ha $\left.{ }^{-1}\right)$. $\mathrm{SN}$, SP and SK are soil test values $\left(\mathrm{kg} \mathrm{h}^{-1}\right)$ for $\mathrm{KMnO}_{4}-\mathrm{N}$, Bray 's $\mathrm{P}$ and ammonium acetate extractable $\mathrm{K}$ and $\mathrm{Y}$ is crop yield. 
Table.3 Relation of grain yield (Y) and total nutrient uptake (U), Nutrient requirement(NR), Efficiencies of fertilizer $\left(\mathrm{E}_{\mathrm{f}}\right)$, soil $\left(\mathrm{E}_{\mathrm{s}}\right), \mathrm{FYM}\left(\mathrm{E}_{\mathrm{org}}\right)$ and Fertilizer Equations for potato

\begin{tabular}{|c|c|c|c|c|c|c|c|}
\hline Nutrients & $\mathbf{Y = b 1 ~ U}$ & $\mathbf{R}^{\mathbf{2}}$ & $\begin{array}{c}\mathbf{N R} \\
\left(\mathbf{k g ~ q}^{-\mathbf{1}}\right)\end{array}$ & $\begin{array}{c}\mathbf{E}_{\mathbf{f}} \\
(\boldsymbol{\%})\end{array}$ & $\begin{array}{c}\mathbf{E}_{\mathbf{s}} \\
(\boldsymbol{\%})\end{array}$ & $\begin{array}{c}\mathbf{E}_{\mathbf{o r g}} \\
(\boldsymbol{\%})\end{array}$ & Fertilizer Equations \\
\hline $\mathbf{N}$ & $\begin{array}{c}\mathrm{Y}=2.065 \\
\mathrm{UN}\end{array}$ & 0.881 & 0.48 & 32.94 & 16.42 & 11.09 & $\mathrm{FN}=1.44 \mathrm{Y}-0.50 \mathrm{SN}-0.34 \mathrm{FYM}$ \\
\hline $\mathbf{P}$ & $\mathrm{Y}=8.818 \mathrm{UP}$ & 0.693 & 0.11 & 28.30 & 64.47 & 5.88 & $\mathrm{FP}=0.39 \mathrm{Y}-2.28 \mathrm{SP}-0.21 \mathrm{FYM}$ \\
\hline $\mathbf{K}$ & $\begin{array}{c}\mathrm{Y}=1.922 \\
\mathrm{UK}\end{array}$ & 0.922 & 0.52 & 97.40 & 18.33 & 5.55 & $\mathrm{FK}=0.53 \mathrm{Y}-0.19 \mathrm{SK}-0.06 \mathrm{FYM}$ \\
\hline
\end{tabular}

Where, FN, FP and FK are fertilizer $\mathrm{N}, \mathrm{P}_{2} \mathrm{O}_{5}$ and $\mathrm{K}_{2} \mathrm{O}\left(\mathrm{Kg} \mathrm{ha}^{-1}\right)$ respectively. FYM is Farm Yard Manure (t ha $\left.{ }^{-1}\right)$. $\mathrm{SN}$, SP and SK are soil test values $\left(\mathrm{kg} \mathrm{ha}^{-1}\right)$ for $\mathrm{KMnO}_{4}-\mathrm{N}$, Bray's $\mathrm{P}$ and ammonium acetate extractable $\mathrm{K}$ and $\mathrm{Y}$ is crop yield in $\mathrm{q} \mathrm{ha}^{-1}$.

Table.4 Ready Reckoners for soil test based fertilizer $\mathrm{N}_{2} \mathrm{O}_{5}$ and $\mathrm{K}_{2} \mathrm{O}$ recommendation of potato (var. Kufri Pukhraj) in midland Inceptisols with 5 tons of FYM

\begin{tabular}{|c|c|c|c|c|c|c|c|c|c|c|c|}
\hline \multirow{2}{*}{\multicolumn{3}{|c|}{$\begin{array}{l}\text { Soil Test values } \\
\left(\mathrm{kg} \mathrm{ha}^{-1}\right)\end{array}$}} & \multicolumn{9}{|c|}{ Yield Target of potato $\left(\mathrm{q} \mathrm{ha}^{-1}\right)$} \\
\hline & & & \multicolumn{3}{|c|}{100} & \multicolumn{3}{|c|}{150} & \multicolumn{3}{|c|}{200} \\
\hline $\mathbf{N}$ & $\mathbf{P}$ & $\mathbf{K}$ & $\mathbf{F N}$ & $\mathbf{F P}$ & FK & FN & $\mathbf{F P}$ & FK & FN & $\mathbf{F P}$ & FK \\
\hline 150 & 4 & 200 & 67 & 29 & 25 & 139 & 48 & 41 & 211 & 68 & 68 \\
\hline 175 & 6 & 225 & 55 & 25 & 25 & 127 & 44 & 37 & 199 & 63 & 63 \\
\hline 200 & 8 & 250 & 42 & 25 & 25 & 114 & 39 & 32 & 186 & 59 & 58 \\
\hline 225 & 10 & 275 & 38 & 25 & 25 & 102 & 35 & 27 & 174 & 54 & 54 \\
\hline 250 & 12 & 300 & 38 & 25 & 25 & 89 & 30 & 25 & 161 & 50 & 49 \\
\hline 275 & 14 & 325 & 38 & 25 & 25 & 77 & 26 & 25 & 149 & 45 & 44 \\
\hline 300 & 16 & 350 & 38 & 25 & 25 & 64 & 25 & 25 & 136 & 41 & 39 \\
\hline 325 & 18 & 375 & 38 & 25 & 25 & 52 & 25 & 25 & 124 & 36 & 35 \\
\hline 350 & 20 & 400 & 38 & 25 & 25 & 39 & 25 & 25 & 111 & 31 & 30 \\
\hline 375 & 22 & 425 & 38 & 25 & 25 & 38 & 25 & 25 & 99 & 27 & 25 \\
\hline 400 & 24 & 450 & 38 & 25 & 25 & 38 & 25 & 25 & 86 & 25 & 25 \\
\hline
\end{tabular}

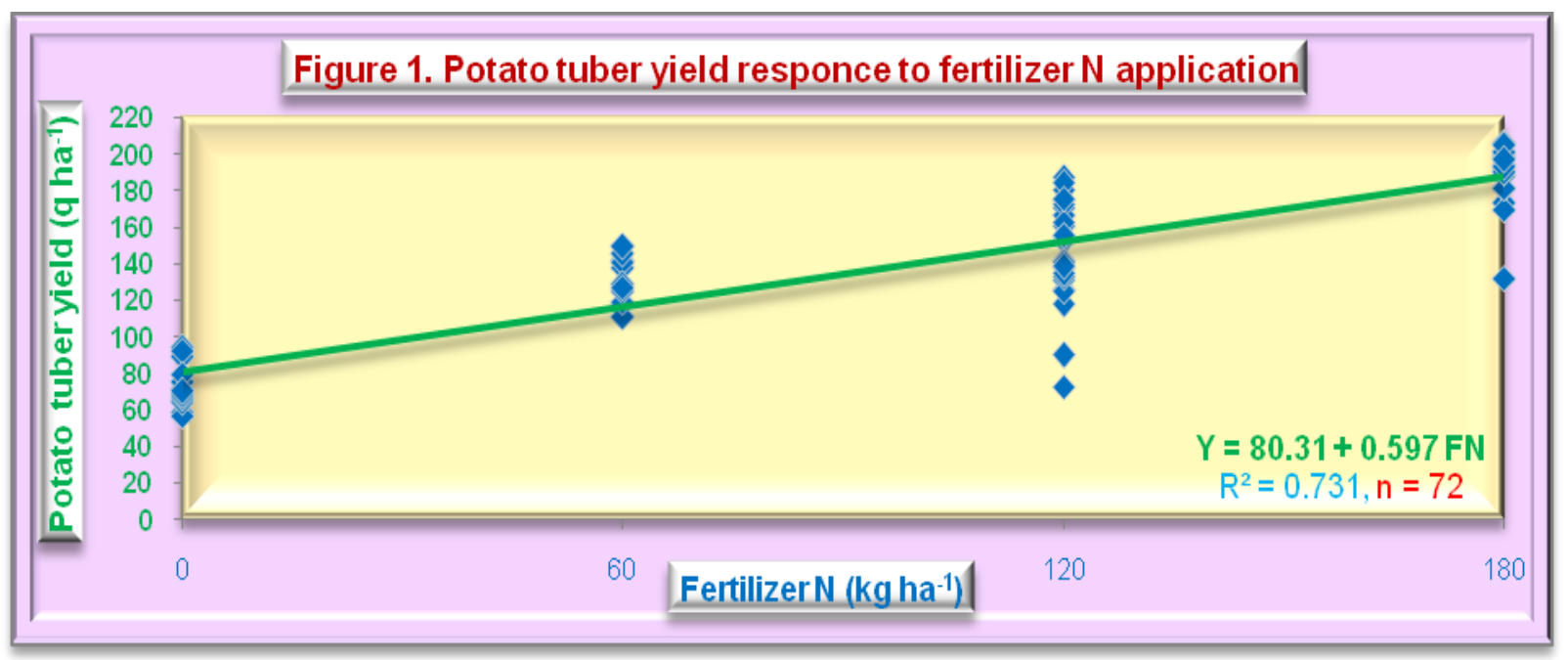



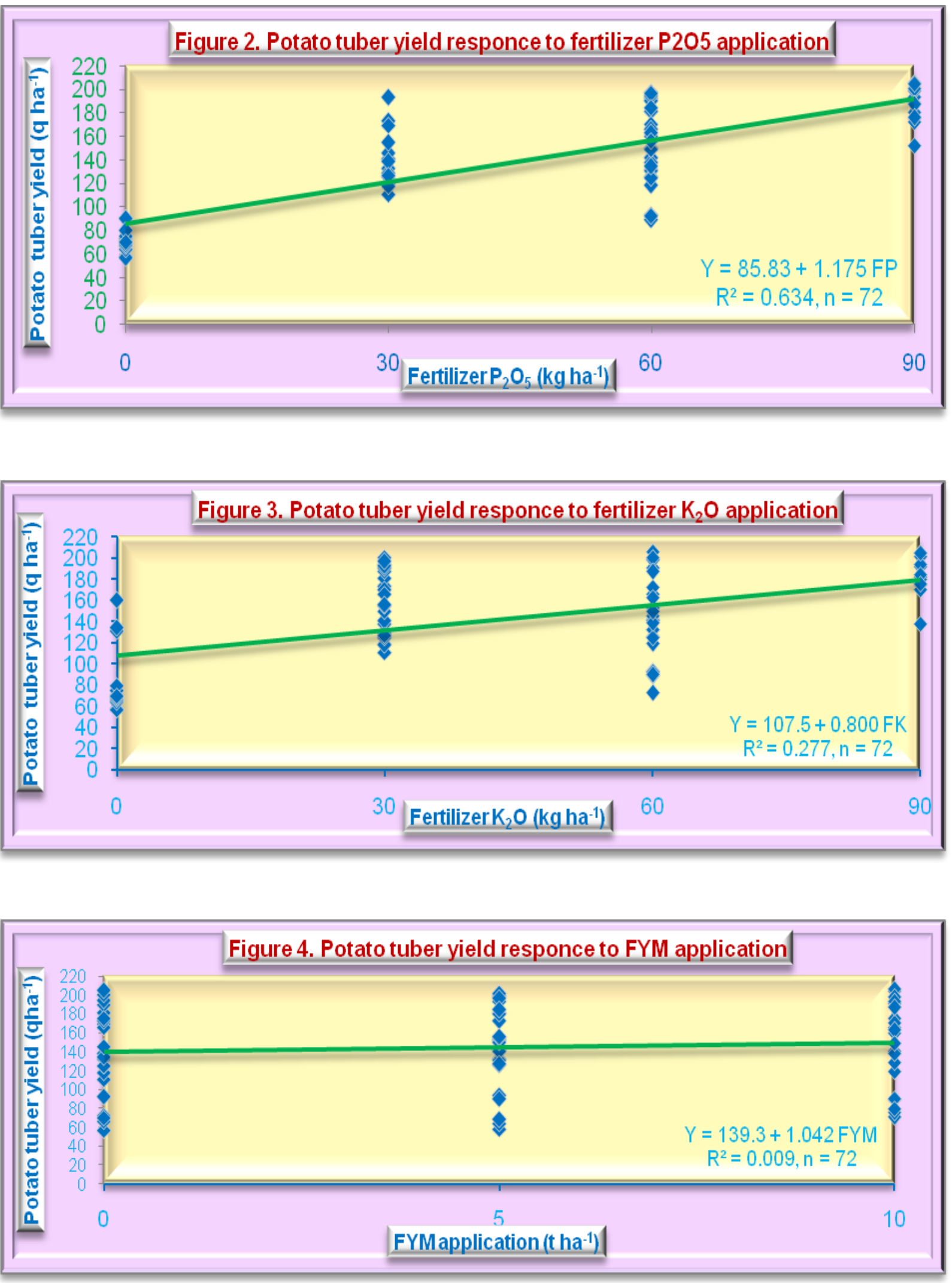

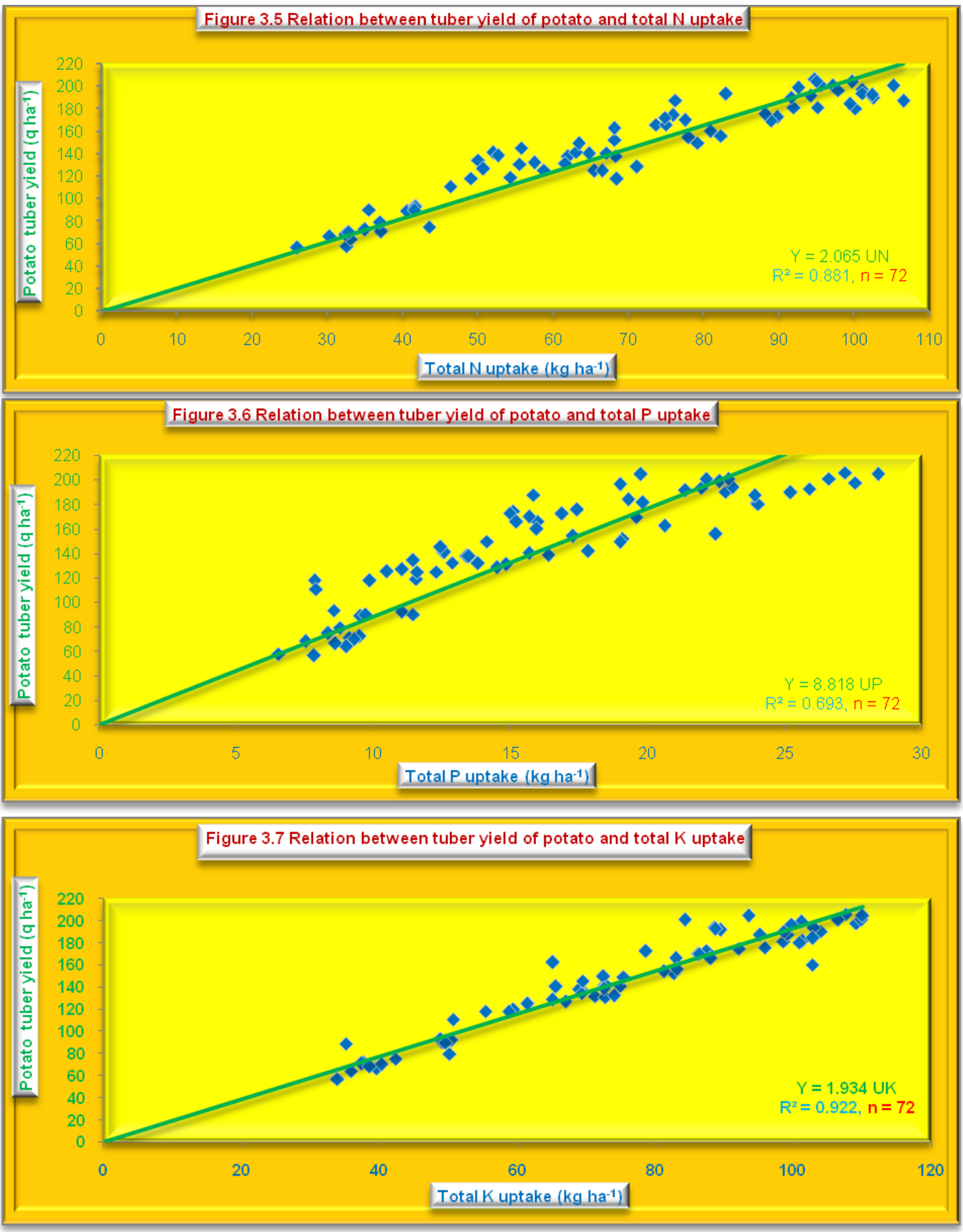
This parameter gives better results with the regression methods which are being followed in present study. Several workers have reported the nutrient requirement of different crops at various places. Ramamoorthy et al., (1967) reported for wheat crop which required $2.5 \mathrm{~kg} \mathrm{~N}, 0.8 \mathrm{~kg} \mathrm{P}_{2} \mathrm{O}_{5}$ and $1.0 \mathrm{~kg}$ $\mathrm{K}_{2} \mathrm{O}$ for one quintal of grain production. Prasad et al., (1981) estimated the nutrient requirement of sugarcane for the production of 1 tonne of cane as $1.71 \mathrm{~kg} \mathrm{~N}, 0.18 \mathrm{~kg} \mathrm{P}_{2} \mathrm{O}_{5}$ and $1.80 \mathrm{~kg} \mathrm{~K}_{2} \mathrm{O}$. Bajendra et al., (2012) reported that the nutrient requirement $\left(\mathrm{kg} \mathrm{q}^{-1}\right)$ of $\mathrm{N}, \mathrm{P}_{2} \mathrm{O}_{5}$ and $\mathrm{K}_{2} \mathrm{O}$ were found to be 6.97 , 1.42 and 1.04 , respectively for producing one quintal of maize yield in Meghalaya. Suri and Verma (2000) found that amounts of nutrients needed to produce one quintal of maize and wheat were 2.30 and $2.35 \mathrm{~kg} \mathrm{~N} 0.81$ and 0.63 $\mathrm{kg} \quad \mathrm{P}_{2} \mathrm{O}_{5}$ and 1.64 and $1.66 \mathrm{~kg} \mathrm{~K}_{2} \mathrm{O}$, respectively. Sharma et al., (2015) reported the nutrient requirement of rice crop as 1.36 $\mathrm{kg} \mathrm{N}, 0.31 \mathrm{~kg} \mathrm{P}_{2} \mathrm{O}_{5}$ and $1.90 \mathrm{~kg} \mathrm{~K}_{2} \mathrm{O}$ per quintal of rice grain produced in Bastar plateau of Chhattisgarh.

\section{Efficiencies of fertilizer, soil test and FYM}

The efficiencies of fertilizer, soil test and FYM were estimated by using the conventional methods with the help of software developed by AICRP on STCR, Indian Institute of Soil Science, Bhopal (MP). The fertilizer efficiencies of $\mathrm{N} \mathrm{P}$ and $\mathrm{K}$ for potato crop were estimated as $32.94,28.30$ and 97.40 per cent, respectively. The efficiencies of soil test for potato were recorded as $16.42 \% \mathrm{~N}, 64.47 \% \mathrm{P}$ and $18.33 \%$ $\mathrm{K}$. The efficiencies of organic source (FYM) were observed as $11.09,5.88,5.55$ per cent $\mathrm{N}$, $\mathrm{P}$ and $\mathrm{K}$ for potato crops, respectively.

It is well known that approximate $2 / 3^{\text {rd }}$ of the applied fertilizer $\mathrm{N}$ lost through leaching, volatilization, de-nitrification and by run-off. Similarly, a large fraction of applied fertilizer
$\mathrm{P}$ is fixed in soil by reacting with dominant cations present in the soil like $\mathrm{Fe}, \mathrm{Mn}, \mathrm{Ca}, \mathrm{Mg}$ etc. High efficiency of applied fertilizer $\mathrm{K}$ observed seems to be due to higher uptake of this nutrient as luxury consumption. Soil test efficiencies for $\mathrm{N}$ and $\mathrm{K}$ were recorded less than fertilizer sources and reverse trend was seen in case of soil test Ramamoorthy et al., (1967) reported the efficiency of soil N, P and $\mathrm{K}$ were 37,14 and 44.0 per cent, respectively and the efficiency of fertilizer $\mathrm{N}, \mathrm{P}$ and $\mathrm{K}$ were 34, 41 and 36 per cent, respectively. Similarly Santhi et al., (2004) reported the contribution of soil and fertilizer nutrients as 14.13 and 38.28 per cent for $\mathrm{N}, 35.33$ and 56.61 per cent for $\mathrm{P}_{2} \mathrm{O}_{5}$ and 14.33 and 70.03 per cent for $\mathrm{K}_{2} \mathrm{O}$, respectively for onion bulb yield in Inceptisols of Tamil Nadu.

\section{Estimation of fertilizer adjustment equations}

Based on the basic parameters viz. nutrient requirement, efficiencies of fertilizer, soil test and organic source (FYM), fertilizer adjustment equations were evolved for potato crop to achieve a definite yield goal. The following equations (Table 3) were evolved for potato for fertilizer $\mathrm{N}, \mathrm{P}_{2} \mathrm{O}_{5}$ and $\mathrm{K}_{2} \mathrm{O}$.

\section{Ready reckoners chart for fertilizer recommendation to potato crop}

The ready reckoners for potato with the use of 5 tonnes of FYM are shown in Table 4. The application of chemical fertilizer with FYM in integrated manner has beneficial effect by several ways in terms of soil fertility and physical properties improvement and higher fertilizer use efficiencies. It is further evident that the fertilizer requirements decreased with increase in soil test values. Therefore, a slightly lower yield target may be considered for a poor resource farmers to obtain maximum profit per unit cost spent on fertilizer, whereas, a higher yield target for a 
resourceful farmers who are interested for maximum potential production per unit area. Hence, for maintaining soil fertility, it is necessary to choose appropriate yield targets and fertilizer use practices that achieve the twin objectives of high yield and maintenance of soil fertility. Thus the targeted yield approach of fertilizer recommendation ensures nutrient balancing to suit the situations involving different yield goals, soil fertility and resources of the farmer (Dev et al., 1985). Several workers have used this approach of fertilizer prescription Patil, (1985) and Acharya et al., (2001).

\section{Acknowledgement}

This Research work is carried out under All India Coordinated Research project for Dryland Agriculture. The authors are grateful to the Central Research Institute for Dryland Agriculture, Indian Council of Agricultural Research, Santosh nagar, Hyderabad for financial support.

\section{References}

Acharya, C. L., Bishnoi, S. K. and Yadhuvanshi, H. S. 1988. Effect of longterm application of fertilizers and organic and inorganic amendments under continuous cropping on soil physical and chemical properties. Indian Journal of Agricultural Sciences, 58: 507-516.

Anonymous, 2011. Area and production of vegetable crops, Directorate of Horticulture, Raipur. Website- http:// agridept.cg.gov.in/agriculture/ horticulture.htm.

Bajendra, Patiram and Singh, L. S. 2012. Soil test based fertilizer recommendation and verification for maize grown in mid hills of Meghalaya. An Asian Journal of Soil Science, 7(1):124-126.

Bray R H (1948) Requirements for successful soil test. Soil Science 66: 83-89.

Chapman H D and Pratt P F (1961) Soil water and plant analysis. In. Univ. California Agri. Div. Publisher.

Dev, G., Dillion, N. S., Brar, J. S. and Vig, A. C. 1985. Soil test based yield targets for wheat arid rice-cropping system. Fert. News, 30(5): 42-50.

Dobermann, A., C. Witt, S. Abdulrachman, H. C. Gines, R. Nagarajan, T. T. Son, P. S. Tan, G. H. Wang, N. V. Chien, and V. T. K. Thoa. 2003. Soil fertility and indigenous nutrient supply in irrigated rice domains of Asia. Agronomy Journal 95:913-23.

Draper, N. R., and H. Smith. 1998. Applied regression analysis. New York: Wiley.

Hanway, J. J., and H. Heidal. 1952. Soil analysis methods as used in Iowa State College. Agriculture Bulletin 57:1-13.

Jackson M L (1973) Soil Chemical analysis. Prentice-Hall of India Pvt Ltd., New Delhi.

Kumar, A., Meena, R. N., Yadav, Lalji and Gilotia, Y. K. 2014. Effect of organic and inorganic sources of nutrient on yield, yield attributes and nutrient uptake of rice cv PRH-10. J. the Bioscan. 9(2): 595-597.

Mandal, Rakesh, Sharma, G.K., Mishra, V.N., Patil, S.K. Srivastava, L.K. and Thakur, D.S. 2016. Fertilizer recommendations based on targeted yield concept involving integrated nutrient management for hybrid maize (Zea mays L.) in Inceptisols of rainfed midlands of Bastar Plateau Zone of Chhattisgarh. Green Farming, 7 (1): 69-73.

Maruthi Sankar, G. R. 1986. On screening of regression models for selection of optimal variable subsets. Journal of Indian Society of Agricultural Statistics 38 (2):161-68.

Mishra, Shiva Autar, Singh, Y. V. and Dey, Pradeep. 2015. Quantitative estimation of fertilizer requirement for chickpea in the alluvial soil of the indo-gangetic plains. The Bioscan, 10(1): 435-438.

Patil, S. K., Mishra, V. N., Das, R. O., Pal, A. R. and Katre, R. K. 1997. Response. 
plateau models for soil test "Phosphorus" calibration. J. Indian Soc. Soil Sci., 45(2): 284-287.

Prasad, B., Prasad, C. R., Mishra, G. K., Verma, S. N. P. and Rai, Y. 1981. Fertilizer requirement for different yield targets of sugar cane based on soil test values in calcareous soils of Bihar. Indian Sugar crops Journal, 8(3):18-20.

Ramamoorth B, Narasimham R L and Dinesh R S (1967) Fertilizer application for specific yield targets of Sonora 64. Indian Farming 17 (5): 43-4.

Regar, Kanhaiya Lal and Singh, Y. V. 2014. Fertilizer recommendation based on soil testing for the targeted yield of rice in eastern plain zone of utter Pradesh. The Bioscan, 9(2): 531-534.

Santhi, R., R. Natesan, K. Andi, and G. Selvakumari. 2004. Soil test based fertilizer recommendation for sunflower (Heliathus annus L.) in Inceptisol of Tamil Nadu. Journal of Oilseed Research 21(1):78-81.

Sharma, G. K., and J. L.Choudhary, 2014. Time trends in temperature of Bastar Plateau agro-climatic zone of Chhattisgarh. Mausam 65 (1): 29-36.

Sharma, G. K., V. N. Mishra, G. R. Maruti Sankar, S. K. Patil, L. K. Srivastava, D. S. Thakur and Ch. Srinivasa Rao (2015) Soil-Test-Based Optimum Fertilizer Doses for Attaining Yield Targets of Rice under Midland Alfisols of Eastern India, Communications in Soil Science and Plant Analysis, 46:17, 2177-2190.

Singh, S., Bhat, Z. A. and Rehman, H. U.
2014. Influence of organic and integrated nutrient management of physic-chemical properties of soil under basmati-wheat cropping sequence. J. Bioscan. 9(4): 1471-1478.

Subbaiah B V and Asija G L (1956) A rapid procedure for determination of available nitrogen in soil. Current Science 25: 259260.

Subba Rao, A. and Srivastava, S. 2000. Soil test based fertilizer use - a must sustainable agriculture. Fertilizer news. 45: 25-38.

Suri, V. K., and T. S. Verma. 2000. Nutrient efficiency and their evaluation maize $(\mathrm{Cv}$. Parvati) and wheat (cv. Aradhana) on farmers' field for prescription-based fertilizer recommendations. Research on Crops, 1(2):128-32.

Truog, E. 1960. Fifty years of soil testing. Transactions of Seventh International Congress of Soil Science 3:46-53.

Velayutham, M., K. C. K. Reddy, and G. R. Maruthi Sankar. 1985a. Soil test crop response research work in India for fertilizer recommendation. In Proceedings of International Symposium on Soil Test Crop Response Correlation Studies, Commission IV of ISSS, BARC and SSSB, Dhaka, Bangladesh, 662-644.

Velayutham, M., K. C. K. Reddy, and G. R. Maruthi Sankar. 1985b. All India Coordinated Research Project on soil test crop response correlation and its impact on agricultural production. Indian Journal of Fertilizers 30 (4):81-95.

\section{How to cite this article:}

Mandal, R. and Sharma, G.K. 2019. Fertilizer Recommendations based on Targeted Yield Concept Involving INM for Potato (Solenum tuberosum L) in Inceptisols of Rainfed Midlands of Bastar Plateau. Int.J.Curr.Microbiol.App.Sci. 8(07): 1629-1639.

doi: https://doi.org/10.20546/ijcmas.2019.807.194 